and to establish whether their advantages outweigh discernable disadvantages, and for control over innovations with a harmful potential. Further standards are likely to be elaborated and mechanisms to be established to ensure that research and its application in these areas are developed in a harmonious way that guarantees human rights for all.

\section{Право на охрану здоровья и медицинскую помощь. Международно- правовые аспекты}

\section{Бушуева В.П.*}

Право каждого человека на охрану здоровья и медицинскую помощь - общепризнанная норма международного права, закрепленная как во Всеобщей декларации прав человека (ст. 25)' пакте об экономических, социальных и культурных правах 2 .

Согласно статье 12 Пакта участвующим в нем государствам предписывается признавать право каждого человека на наивысший достижимый уровень физического и психического здоровья. Государстваучастники должны принимать меры для полного осуществления этого права, включая мероприятия, необходимые для сокращения мертворождаемости, детской смертности, для обеспечения здорового развития ребенка, улучшения всех аспектов гигиены, предупреждения и лечения эпидемических, эндемических, профессиональных и иных болезней. В соответствии с п. 2 ст. 10 Пакта особая охрана должна предоставляться матерям в течение разумного периода до и после родов ${ }^{3}$.

В России в соответствии со ст. 17 Конституции признаются и гарантируются права и свободы человека и гражданина согласно общепризнанным принципам и нормам международного права. Среди конституционных прав и свобод человека названы: право на жизнь (ст. 20), право на охрану здоровья и медицинскую помощь (ст. 41), право на охрану достоинства личности (ст. 21), право на свободу и личную неприкосновенность (ст. 22), право на неприкосновенность частной жизни, личную и семейную тайну (ст. 23).

В соответствии со ст. 41 Конституции каждый имеет право на охрану здоровья и медицинскую помощь. При этом, однако, следует констатировать, что Международный пакт об экономических, социальных

\footnotetext{
* Бушуева Виктория Павловна - соискатель МИУ МГИМО(У) МИД России.

${ }^{1}$ Международное публичное право. Сборник документов. Т. 1. М.: БЕК, 1996. С. 460-464

${ }^{2}$ Там же. С. 464-470

${ }^{3}$ Там же.
} 
и культурных правах трактует право на медицинскую помощь шире, чем Конституция Российской Федерации. Последняя не говорит, к примеру, о необходимости достижения наивысшего уровня физического и психического здоровья нации и отдельного индивида. Таким образом, учитывая, что Российская Федерация является участником указанного Пакта, в силу ч. 4 ст. 15 Конституции Российской Федерации органы государственной власти и органы местного самоуправления должны обеспечивать реализацию права на медицинскую помощь в объеме не ниже установленного Пактом. Это существенно расширяет правовое содержание права российских граждан на охрану здоровья и медицинскую помощь.

После принятия Международного пакта об экономических, социальных и культурных правах Генеральной Ассамблеей ООН была провозглашена Декларация социального развития и прогресса (11 декабря 1969 г. $)^{4}$. Этот документ является международным политическим актом и не содержит норм права. Однако его принятие имеет немалое значение для утверждения и развития международных правовых стандартов в области социально-экономических и культурных прав человека.

Как и Международный пакт, Декларация призывает мировое сообщество обеспечить достижение самого высокого уровня здравоохранения и охраны здоровья всего населения по возможности бесплатно (п. «d» ст. 10). Целями социального развития и прогресса согласно Декларации являются также охрана прав матери и ребенка, забота о воспитании и здоровье детей, проведение мероприятий, направленных на охрану здоровья женщин, и особенно работающих матерей во время беременности и младенческого возраста их детей (п. «b» ст. 11). Средствами достижения указанных целей, обозначенными в Декларации, являются планирование социального прогресса и развития, учреждение национальных систем по разработке и проведению в жизнь социальной политики и программ на основе широкого общественного участия. Отдельное внимание в Декларации уделено национальным системам здравоохранения (ст. 19). Они должны основываться на предоставлении бесплатного обслуживания в области здравоохранения всему населению и обеспечении того, чтобы соответствующие профилактические и лечебные учреждения, а также медицинское обслуживание были доступны всем ${ }^{5}$.

${ }^{4}$ См.: Консультант-Плюс.

${ }^{5}$ Там же.
С учетом установления аналогичных правовых стандартов в Международном пакте об экономических, социальных и культурных правах можно предположить, что по поводу рассмотренных выше положений Декларации в мировом сообществе складывается opinio juris, то есть они приобретают обязательную силу для государств - членов ООН.

В международном праве право на медицинскую помощь регулируется не только на универсальном уровне, но и на региональном. Важнейшим документом регионального уровня является Европейская социальная хартия 1961 г. (в редакции 1996 г.). Россия подписала Хартию 14 сентября 2000 г. (Распоряжение Президента РФ от 12 мая 2000 г. № 151-рп). Однако пока Хартия не вступила в силу для России.

Нормы Европейской социальной хартии являются составной частью стандартов Совета Европы в области прав человека. В них не последнее место занимает обеспечение права на медицинскую помощь ${ }^{6}$. При этом в отличие от классических институтов права международных договоров стандарты Совета Европы в области прав человека представляют собой односторонние обязательства признающих их государств. В этом смысле составляющие их нормы являются нормами јus cogens (ст. 53 Венской конвенции о праве международных договоров). Другая важная особенность стандартов Совета Европы в том, что они закрепляют обязательства государств не столько по отношению друг к другу, сколько к частным лицам, находящимся под их юрисдикцией ${ }^{7}$.

Особая природа стандартов Совета Европы предопределяет их соотношение с национальным правом. В литературе отмечается приоритет права Совета Европы над национальным правом, указывается на большие изменения, которые претерпевало право отдельных государств под влиянием Европейской конвенции о защите прав человека и основных свобод и практики ее применения. В этом смысле следует говорить о сходстве природы «социальных» стандартов Совета Европы и норм Международного пакта об экономических, социальных и культурных правах (в их «Лимбургской» трактовке) $)^{8}$. Это тем более важно,

${ }^{6}$ См.: Гомьен Д., Харрис Д., Зваак Л. Европейская конвенция о правах человека и Европейская социальная хартия: право и практика. М., 1998. С. 27, 31; Тиунов О.И. Международное гуманитарное право. М., 1999. С. 209; Карташкин В.А. Права человека в международном и внутригосударственном праве. М., 1995. С. 9.

${ }^{7}$ Права человека: постоянная задача Совета Европы. М., 1996. С. 13-14, 102-106;

${ }^{8}$ См.: Карташкин В.А. Международное право и защита прав человека в условиях перехода к рынку// Социальное государство и защита прав человека. М., 1994. С. 47; «Лимбургские принципы» и комментарий Л.Н. Шестакова опубликованы: Вестник МГУ. Серия 11.1996. № 2. С. 76-89. 
что роль Европейской социальной хартии в системе стандартов Совета Европы неуклонно возрастает. Европейская доктрина рассматривает ее как дополнение к Европейской конвенции о защите прав человека и основных свобод, поскольку оба документа имеют единый предмет правового регулирования (права и свободы человека). Как представляется, в его основе лежит принцип единства, взаимосвязи и взаимообусловленности гражданских, политических, социальноэкономических и культурных прав и свобод.

Однако механизм реализации норм Конвенции и Хартии различен, поскольку Хартия не имеет самостоятельной юрисдикционной защиты и контроль по ней ограничивается представлением докладов.

Как представляется, для успешной реализации Хартии необходимо распространить на закрепленные ею обязательства государств юрисдикцию Европейского Суда по правам человека. Такая мера будет самым лучшим образом способствовать быстрому и эффективному претворению в жизнь социальных стандартов Совета Европы. Как в свое время Европейский Суд в тесном взаимодействии с Европейской комиссией по правам человека «вдохнул жизнь»" в Европейскую конвенцию о защите прав человека и основных свобод, так он может обеспечить «новую жизнь» и Европейской социальной хартии. Рассматриваемое нововведение может оказаться полезным и с точки зрения реализации конституционного права российских граждан на медицинскую помощь, поскольку Суд, вероятно, выработает конкретные требования к праву социального обеспечения в демократических государствах, в том числе и в части гарантий права на охрану здоровья и права на медицинскую помощь.

Согласно п. 11 ч. 1 Хартии каждый человек имеет право пользоваться всеми средствами, способствующими достижению им наилучшего возможного для него состояния здоровья. При этом в соответствии с п. 13 указанной части каждый человек, не имеющий достаточно средств к существованию, имеет право на социальную и медицинскую помощь. Кроме того, все трудящиеся имеют право на условия труда, отвечающие требованиям безопасности и гигиены (п. 3 ч. 1 Хартии).

Перечисленные нормы Хартии составляют основные принципы правовых стандартов Совета Европы в области права на медицинскую

${ }_{9}^{9}$ См.: Энтин М.Л. Международные гарантии прав человека (практика Совета Европы). М., 1992. С. 8-11; Европейская конвенция о защите прав человека и основных свобод: проблемы реализации в России. Материалы Международного семинара. Т. I. Нижний Новгород, 1999. С. 23-25. помощь. Их содержание раскрыто во второй части Хартии, которая достаточно подробно регламентирует реализацию этого права.

Так, согласно ст. 11 ч. 2 Хартии государства-участники в целях обеспечения эффективного осуществления права на охрану здоровья обязаны принять непосредственно или в сотрудничестве с государственными или частными организациями меры, направленные, в частности, на устранение причин ухудшения здоровья, предоставление услуг консультационного и образовательного характера, а также предотвращение эпидемических, эндемических и других заболеваний.

Статья 13 Европейской социальной хартии устанавливает право на социальную и медицинскую помощь. В контексте рассматриваемого положения Хартии договаривающиеся стороны обязуются обеспечить, чтобы каждому лицу, которое не имеет достаточно средств к существованию и которое не в состоянии ни добыть их собственными усилиями, ни получить их из других источников, в частности благодаря выплатам в рамках системы социального обеспечения, была бы предоставлена соответствующая помощь, а при болезни - необходимый уход.

Если сравнить рассмотренные выше положения Международного пакта об экономических, социальных и культурных правах и Европейской социальной хартии, можно установить, что трактовка права на медицинскую помощь в европейском праве отличается от трактовки в универсальных международно-правовых актах, прежде всего по объему. Как отмечалось выше, Международный пакт и Декларация социального развития и прогресса указывали на необходимость обеспечения наивысшего, максимально возможного уровня физического и психического здоровья каждого индивида и, кроме того, содержали ряд конкретных предписаний государствам-участникам по реализации вышеизложенного требования. В то же время Европейская социальная хартия оставляет конкретную трактовку права на медицинскую помощь на усмотрение государствам-участникам и содержит массу оговорок, позволяющих толковать ееположения ограничительно.

Возвращаясь к вопросу о международных правовых стандартах в области права на медицинскую помощь, необходимо отметить, что это право закреплено также международными правовыми актами на уровне СНГ. В частности, Конвенция о правах и основных свободах человека, подписанная в Минске 26 мая 1995 г., содержит положения (ст. 15 и 16 в соответствующей части), практически полностью повторяющие ст. 11 и 13 ч. 2 Европейской социальной хартии. Таким обра- 
зом, для Российской Федерации, являющейся участником как Европейской социальной хартии, так и Конвенции СНГ, соответствующие нормативные положения действуют в «двойном объеме»-как для члена Совета Европы и как для участника СНГ. Следовательно, данные положения обеспечиваются юрисдикционной защитой на уровне Совета Европы и на уровне СНГ.

Завершая анализ международных правовых актов, которые в соответствии с ч. 4 ст. 15 Конституции Российской Федерации составляют конституционную основу права человека на медицинскую помощь (наряду с положениями Конституции Российской Федерации, непосредственно закрепляющими это право), необходимо отметить, что Российское государство обязано обеспечивать более высокий уровень гарантий права на медицинскую помощь, чем тот, который прямо вытекает из Конституции Российской Федерации.

\section{The Right to Health Protection and Medical Aid. International Law Aspects (Summary)}

\section{Viktoria P. Bushueva*}

Health is increasingly seen as a key aspect of human security, and occupies a prominent place in debates on the priorities for development. This article contains an expert assessment of the current crisis in the sphere of health protection in Russia and proposals to tackle it over the next years, starting immediately. According to Article 25 of Universal Declaration of Human Rights adopted and proclaimed by General Assembly resolution 217 A(III) of 10 December 1948 everyone has the right to a standard of living adequate for the health and well-being of himself and of his family, including food, clothing, housing and medical care and necessary social services, and the right to security in the event of unemployment, sickness, disability, widowhood, old age or other lack of livelihood in circumstances beyond his control.

The Constitution of the Russian Federation has proclaimed that everyone shall enjoy the right to health protection and medical aid. Medical aid in

"Viktoria P. Bushueva - post-graduate student of the International institute of management, MGIMO University MFA Russia. state and municipal health establishments shall be rendered to individuals gratis, at the expense of the corresponding budget, insurance contributions and other proceeds.

Main issues of the article are implementation of federal programs for protecting and improving the health of the population financed by the State; the necessity of measures to be adopted to develop state, municipal and private health services; promotion of activities which facilitate the improvement of health, the development of physical culture and sport, ecological and sanitary-epidemiological well-being. 